\title{
2021 Handbook of Florida Water Regulation: Florida Springs and Aquifer Protection Act ${ }^{1}$
}

\author{
Tatiana Borisova, Michael T. Olexa, and Jana Caracciolo ${ }^{2}$
}

\section{Preface}

This handbook is designed to provide an accurate, current, and authoritative summary of the principal federal and state (Florida) laws that directly or indirectly relate to agriculture. This handbook provides a basic overview of the many rights and responsibilities that farmers and farmland owners have under both federal and state laws as well as the appropriate contact information to obtain more detailed information. However, the reader should be aware that because the laws, administrative rulings, and court decisions on which this handbook is based are subject to constant revision, portions of this publication could become outdated at any time. Several details of cited laws are also left out due to space limitations. This handbook is provided as an educational text for those interested in water use and water resource issues in Florida.

This handbook is distributed with the understanding that the authors are not engaged in rendering legal or other professional advice, and the information contained herein should not be regarded as a substitute for professional advice. This handbook is not all inclusive in providing information to achieve compliance with the federal and state laws and regulations governing water protection. For these reasons, the use of these materials by any person constitutes an agreement to hold harmless the authors, the UF/IFAS Center for Agricultural and Natural Resource Law, and UF/IFAS Extension for any liability claims, damages, or expenses that may be incurred by any person as a result of reference to or reliance on the information contained in this handbook. Note: UF/IFAS is the acronym for University of Florida, Institute of Food and Agricultural Sciences.

\section{FSAPA Overview}

Springs are extremely important for the state of Florida, providing vast natural, recreational, and economic values. They provide scientific value and offer critical habitats for plants and animals (including endangered or threatened species). Springs also serve as indicators of the conditions of the Floridan aquifer, the underground freshwater reserve that is the source of drinking water for the majority of Floridians.

In 2016, the Florida Springs and Aquifer Protection Act (FSAPA) was created to protect springs fed by the Floridan aquifer. FSAPA addresses problems due to pollution, declining flows, ecological imbalances, and activities (such as agricultural and urban landscape practices, leaking septic systems, or inadequate stormwater management) within the surrounding areas of the springs. In addition, FSAPA addresses issues concerning the aquifer and springs system function and delineates springshed boundaries (i.e., the boundaries of the area that contributes to the spring flow).

1. This is EDIS document FE1019, a publication of the Food and Resource Economics Department, UF/IFAS Extension. Original publication date July 2017. Revised April 2021. Please visit the EDIS website at https://edis.ifas.ufl.edu for the currently supported version of this publication.

2. Tatiana Borisova, associate professor, Food and Resource Economics Department, UF/IFAS Extension; Michael T. Olexa, professor, Food and Resource Economics Department, and director, UF/IFAS Center for Agricultural and Natural Resource Law, UF/IFAS Extension, and member of The Florida Bar; and Jana Caracciolo, student, Levin College of Law, University of Florida; Gainesville, FL 32611.

The Institute of Food and Agricultural Sciences (IFAS) is an Equal Opportunity Institution authorized to provide research, educational information and other services

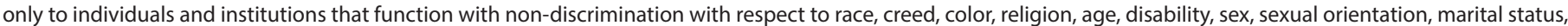

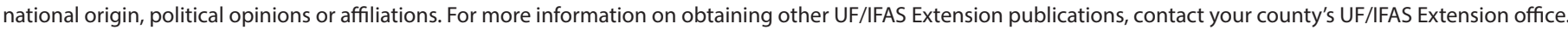
U.S. Department of Agriculture, UF/IFAS Extension Service, University of Florida, IFAS, Florida A \& M University Cooperative Extension Program, and Boards of County Commissioners Cooperating. Nick T. Place, dean for UF/IFAS Extension. 


\section{Outstanding Florida Springs}

Outstanding Florida Springs are defined as all historic first magnitude springs (determined using the most recent Florida Geological Survey springs bulletin). The following springs have been added to the Outstanding Florida Springs classification: De Leon Springs, Peacock Springs, Poe Springs, Rock Springs, Wekiwa Springs, and Gemini Springs.

\section{Water Quantity and Flow Protection}

FSAPA complements and strengthens other policies protecting water. Specifically, the Florida Water Resources Act requires the five Florida Water Management Districts (FWMDs) to develop and submit to the Florida Department of Environmental Protection (FDEP) a priority list of water bodies for which they will establish minimum water flows and water levels. The minimum flow for a given watercourse is the limit at which further withdrawals would be significantly harmful to the water resources or ecology of the area. The minimum water level is the level of groundwater in an aquifer and the level of surface water at which further withdrawals would be significantly harmful to the water resources or ecology of the area.

Following the requirements of FSAPA, FWMDs have adopted minimum flows and water levels for the Outstanding Florida Springs within their individual districts, with the exception of the Northwest Florida Water Management District which has until 2026 to adopt such flows and levels. For an Outstanding Florida Spring below or projected within twenty years to fall below the minimum flow or water level, FWMDs or FDEP must adopt a recovery or prevention strategy that includes

- A prioritized list of specific projects

- The estimated benefits and costs of projects

- The estimated dates of completion of projects

- Financial assistance by FWMDs

The strategy should have the target of achieving minimum flows or minimum levels within twenty years after the adoption of the strategy. The milestones to be achieved within five-year intervals should also be developed (with possible single five-year or ten-year extensions granted to local governments for specific projects).

FSAPA requires FDEP, in coordination with FWMDs, to delineate Priority Focus Areas for Outstanding Florida Springs. A Priority Focus Area is an area of a basin where the Floridan aquifer is most vulnerable to pollutant inputs and where there is a known connectivity between groundwater pathways and an Outstanding Florida Spring. In 2016, the Florida Legislature identified thirty Outstanding Florida Springs as Priority Focus Areas.

FDEP has developed restoration plans aimed to address nitrogen pollution in Florida's springs. These restoration plans are known as Basin Management Action Plans (BMAPs). The BMAPs set a blueprint for achieving the total maximum daily load (TMDL) goal in each impaired spring. Simply put, TMDL is a total limit on nutrient pollution that can be put into a spring, and BMAP is a plan of actions to reduce the total pollution to the amount below or equal to this limit.

A BMAP for Outstanding Florida Springs must include, at a minimum:

- A list of all specific projects and programs identified in the BMAP to implement a nutrient total maximum daily load (TMDL).

- A priority ranking for each project.

- The nutrient pollution point or nonpoint sources (including, but not limited to urban turf fertilizer, sports turf fertilizer, agricultural fertilizer, and onsite sewage treatment and disposal systems).

- An estimated cost and completion date for each project.

- The source and amount of financial assistance to be made available by FDEP, FWMDs, or other entities for each listed project.

- An implementation plan designed with a target to achieve the nutrient TMDL no more than twenty years after the adoption of a BMAP.

The target for achieving the nutrient TMDL should be no more than twenty years after the adoption of a BMAP, with targets established for five-year, ten-year, and fifteen-year intervals, which will be used to determine planning and funding. A single five-year or ten-year extension can be granted to local governments for specific projects.

\section{Water Quality Protection and Restoration}

As part of a BMAP in basins with Outstanding Florida Springs where at least twenty percent of the nonpoint source (diffuse) nitrogen pollution is caused by onsite sewage treatment and disposal systems (such as septic tanks), FDEP must develop an onsite sewage treatment and 
disposal remediation plan. The remediation plan should identify projects to reduce nutrient pollution from the systems, including such options as repair, upgrade (e.g., addition of a new advanced nitrogen-removing technology), or replacement of the systems; connection to a central sewage system; or other actions. Priority ranking of the systems that require remediation should be developed, and FDEP should provide (all or part of) the funding required to implement the remediation actions.

No new onsite sewage treatment and disposal system can be placed on lots of less than one acre unless the system is allowed in the BMAP because the system is recognized to have advanced nitrogen-removing capability.

In addition, a public education plan must also be developed to provide local residents with information about springs and onsite sewage treatment and disposal systems.

Local governments within a Priority Focus Area are required to adopt ordinances to regulate the use of pollutioncausing fertilizers. Since July 1, 2017, all local government are required to develop, enact, and implement an ordinance that meets the necessary requirements in the Model Ordinance for Florida-Friendly Fertilizer Use on Urban Landscapes. Local governments may have adopted additional or more stringent requirements, if necessary, to adequately address urban fertilizer contributions to nonpoint source nutrient loading to a water body. For more information on the Model Ordinance for Florida-Friendly Fertilizer Use on Urban Landscapes, see https://floridawaterstar.com/pdfs/ FF_landscape_guidance_models.pdf.

FSAPA prohibits the following activities within a Priority Focus Area in effect for an Outstanding Florida Spring:

- New large domestic wastewater facilities that do not meet the advanced wastewater treatment standard of $3 \mathrm{mg} / \mathrm{L}$ total nitrogen (or more stringent standards if deemed appropriate).

- New septic tanks on lots of less than one acre (unless the system is allowed in the BMAP because the system is recognized to have advanced nitrogen-removing capability).

- New hazardous waste disposal facilities.

- Land application of wastewater biosolids not in accordance with FDEP approved plan.

- New agricultural operations that do not implement BMPs or groundwater monitoring plans.

\section{FSAPA Agencies}

The following agencies should coordinate activities to restore and maintain spring water quality and quantity: the Florida Department of Agriculture and Consumer Services (responsible for the development and implementation of agricultural best management practices), the Florida Department of Environmental Protection (focusing on water quality protection), the Florida Water Management Districts (focusing on water quantity regulations), and local governments (working on domestic wastewater and stormwater management).

\section{FSAPA for Agriculture}

Fertilizer and irrigation water are important inputs into agricultural production, and it is important to follow the best practices to minimize potential adverse impact of agricultural production on water resources. Agricultural operations in areas with adopted BMAPs (including BMAPs for Outstanding Florida Springs) are required to implement best management practices (BMPs) from the manuals adopted by the Florida Department of Agriculture and Consumer Services or monitor water quality at their own expense (https://www.fdacs.gov/Agriculture-Industry/ Water/Agricultural-Best-Management-Practices).

Furthermore, in areas with minimum flows and water levels, FWMDs will use the minimum flows and water levels to evaluate the applications for consumptive use permits for water withdrawals to make sure the permits would not cause significant harm to the environment. This may change the requirements for the consumptive use permit applications (including permits to withdraw water for agricultural irrigation).

Finally, agricultural producers using septic tanks need to follow the discussions related to the contribution of septic tanks to water quality issues in the Priority Focus Areas. As part of a BMAP in basins with Outstanding Florida Springs where at least twenty percent of the nonpoint source (diffuse) nitrogen pollution is caused by onsite sewage treatment and disposal systems (such as septic tanks), FDEP requires an onsite sewage treatment and disposal remediation plan. The remediation plan should identify projects to reduce nutrient pollution from the systems, including such options as repair, upgrade (e.g., addition of a new advanced nitrogen-removing technology), or replacement of the systems; connection to a central sewage system; or other actions. 


\section{Source}

Chapter 373, Florida Statutes, Sections 373.801-373.813

\section{Acknowledgments}

The authors are indebted to the personnel of both state and federal agencies who provided their time and advice in the preparation of this handbook. We acknowledge Carol Fountain and Susan Gildersleeve at the University of Florida for their assistance in editing this handbook. We also acknowledge funding received for updating this publication from the James S. and Dorothy F. Wershow Agricultural Law Endowment. 